\title{
AN ANALYSIS OF TRANSLATION DIFFICULTIES ON BARRACK OBAMA'S SPEECH TEXT AT SIXTH SEMESTER STUDENTS OF MUHAMMADIYAH UNIVERSITY OF TANGERANG
}

\author{
${ }^{1}$ Nasrul Hasan, ${ }^{2}$ Moh. Iqbal Firdaus, ${ }^{3}$ Yudhie Indra G \\ 123 English Education Study Program Teachers Training and Education Faculty \\ Muhammadiyah University of Tangerang \\ E-mail Correspondence: yudhie.indra@yahoo.com
}

\begin{abstract}
English is international language that used by people in this world to get something like knowledge, information, and communication. In Indonesia, English used as school subject because English is important to students' future in their careers, especially interaction with foreigner, because in Indonesia many interesting destination for foreigner, media and technology use English to inform the information or knowledge. Those are reasons, Indonesian must be able to understand English especially in words meaning in English, because translation is important to know information which use English media. ). For this research, the researchers use descriptive analysis research. The researchers directly find accurate data of difficulties in translating from source language into target language or SL into TL. The researchers have got students' test result, based on the result it shows that the students still confuse to convey the meaning from source language, the students translate the text word by word and the meaning not deliver, and the researchers have got students' test result, based on the result it shows that the students could not to use equivalent, they still lack of vocabulary mastery, they could not translate the sentence, because in English one word has many meaning, and confuse how to use equivalent words in translation that they states from interview "i still lack of vocabulary mastery" and "in English one word many meaning thus we could not translate the sentence because depend on the topic".
\end{abstract}

Key words: Translation Difficulties, Barrack Obama's Speech

\section{INTRODUCTION}

English is international language that used by people in this world to get something like knowledge, information, and communication. In Indonesia, English used as school subject because English is important to students' future in their careers, especially interaction with foreigner, because in Indonesia many interesting destination for foreigner, media and technology use English to inform the information or knowledge. Those are reasons, Indonesian must be able to understand English especially in words meaning in English, because translation is important to know information which use English media.

English especially in word meaning in English, students should learn how to translate well, in order to their result of translation could understand by their selves and especially people. 
Globish (An English-Indonesian journal for English, Education and Culture)

Vol. 9 No. 2 July 2020

P-ISSN: 2301-9913, E-ISSN: 2597-9132

DOI: http://dx.doi.org/10.31000/globish.v7i2

Thus, to know result of students' translation, researcher has done observation.

Based on result of observation, researcher found evidence from students' result of translation study, there is could not understandable from the result of students' translation, students still translate the SL into TL word for word, and some students using google translate. From this research, the researchers found that the students of result translation still low, and some students were lazy for practicing especially to translate the sentences, because mostly still using google translate.

Based on the research that have done by the researchers, the teacher of translation subject wishes the students to learn by their selves, it means looking for something related to the translation subject, it is based on the curriculum of 2013. Thus, the reality found several problems that the students feel, such as: First, high technology could be factor the students not utilizing to learn but for playing online game. Second, from the students self mostly could not wasting time to do their assignment or task of translation, thus the students only translate their task through using google translate. And third, the students are seldom to practice of their translating, it is could be the factor of bad result in their translating. For getting good result of translation, before translating the text, we should reading and understanding the text, in order to understand the message or information, and especially understand by people.

Thus, based on explanation above Translation is important learned, because when we want to know information such as by the text, we should understand the text word by word in order to be good sentences in target language and easy to understand especially Indonesian. From this research, the researcher found the evidence those students especially when transferring source into their target language, many from the students translating the text word by word. Nord (2005) states "Difficulties in translation do not only result from the nature of a source text and its situation in relation to all the possibilities of the target language" (Tarigan, 2018, p.114). based on the states above, to do translate source language should not word by word, but translate the text naturally based on the means and not changes the meaning.

If the message that translated by students there is mistake a word to transfer, it affects in acquiring information. Such as the real case coming from Erry Silviana's research, According to Brown (2000) states that "Mistakes, misjudgments, miscalculations, and error form an important aspect of learning in acquiring information" (Silviana. 2008, p.1). 
Globish (An English-Indonesian journal for English, Education and Culture)

Vol. 9 No. 2 July 2020

P-ISSN: 2301-9913, E-ISSN: 2597-9132

DOI: http://dx.doi.org/10.31000/globish.v7i2

Difficulties in translating is when someone who translates the text, but does not understand how to use adverb, verb, noun so that the sentences are not perfect. Difficulties are usually coming from the student it self, such as the students do not know how deliver message from SL into TL. For example, source language (to leave any final resolution to future generations). A student translates "untuk meninggalkan resolusi akhir apapun dimasa masa depan generasi" the target language difficult to understand by reader, because the student translates word by word, thus the messages incomplete. On the other hand, difficulties happen in how to use equivalent words in translating. For Example, (launched America's improbable experiment in democracy). A student translate "meluncurkan eksperimen mustahil Amerika dalam demokrasi" based on the context Obama's speech text, word "launched" can be improved to another meaning word but not change the message from the speech text, if "meluncurkan" is not appropriate. Thus, the student has difficulties translating that sentences because the students do not know how to use equivalent words and delivering message according to the context.

From this research is the teacher could improve for teaching their student to be well than before, knowing difficulties from students in their translation skill, and giving the students more practice to translate source text. To sum up from the explanation above that the teacher should knowing students problem in translation class.

Knowing problems in translation skill, the researchers are interested in using the speech text of barrack obama's because he's speech good grammatically and very educate. The students could translate through the text. On title "An Analysis of translation Difficulties on Barrack Obama's Speech text at sixth semester students of Muhammadiah University of Tangerang".

\section{RESEARCH METHOD}

In this research, researchers want to know student's difficulties in translating. Thus, the researchers use qualitative approach. As Sugiyono (2015) states that "Qualitative research is research method based on philosophy of post positivisme, used to research nature object, where researcher as the key instrument, the sample is purposive"(p.15). For this research, the researchers use descriptive analysis research. The researcher directly find accurate data of difficulties in translating from source language into target language or SL into TL. And there are the procedures of research, namely: 
Globish (An English-Indonesian journal for English, Education and Culture)

Vol. 9 No.2 July 2020

P-ISSN: 2301-9913, E-ISSN: 2597-9132

DOI: http://dx.doi.org/10.31000/globish.v7i2

1. The first, researchers meet with the Lecturers' Translation of English Study Program in Teacher Training and Education Faculty to ask the principle's of permission to allow conduct the research.

2. The second, reserachers arrange the time for doing the observation.

3. The third, researchers do observation.

4. The fourth, researchers give a test to the students.

5. The fifth, the students do the test in the classroom. The students are given 30 minutes for translating part of Obama's speech.

6. The last, researchers analyzes the students' translation.

The researchers choose the source of this research is the student's difficulties in translating of Muhammadiyah University of Tangerang, and for the data of research, the researcher will use primary data and secondary data.

1. Primary Data

In primary data, the researchers have documents of students translation result of Barrack Obama's speech of Muhammadiyah University of Tangerang.

Bellow the text of Barrack Obama's race speech at the constitution center, March 18, 2008. Published on PDF. http://constitutioncenter.org/amoreperfectunion/docs/Race Speech Transcript.pdf Accessed on Saturday, October 20, 2018. Time of West Indonesia 14.49.

\section{Table.1.1}

Text of speech

\footnotetext{
"We the people, in order to form a more perfect union."
}

Two hundred and twenty one years ago, in a hall that still stands across the street, a group of men gathered and, with these simple words, launched America's improbable experiment in democracy. Farmers and scholars; statesmen and patriots who had traveled across an ocean to escape tyranny and persecution finally made real their declaration of independence at a Philadelphia convention that lasted through the spring of 1787 . The document they produced was eventually signed but ultimately unfinished. It was stained by this nation's original sin of slavery, a question that divided the colonies and brought the convention to a stalemate until the founders chose to allow the slave trade to continue for at least twenty more 

Constitution that promised its people liberty, and justice, and a union that could be and should be perfected over time.

2. Secondary Data

In secondary data, the researchers have evidences data from observation and interview related to the research, to support the theoretical framework. The researchers also have observation data of the students.

\section{RESULT AND DISCUSSION}

\section{Students' difficulties in delivering message from source language into target language.}

The researchers have got students' test result, based on the result it shows that the students still confuse to convey the meaning from source language, the students translate the text word by word and the meaning not deliver. For example : and to leave any final resolution to future generations. Students translation "dan meninggalkan resolusi akhir apapun di masa depan generasi".

\section{Students' difficulties in using equivalent words from source language into target language.}

The researchers have got students' test result, based on the result it shows that the students could not to use equivalent, they still lack of vocabulary mastery, they could not translate the sentence, because in English one word has many meaning, and confuse how to use equivalent words in translation that they states from interview " $\mathrm{i}$ still lack of vocabulary mastery" and "in English one word many meaning thus we could not translate the sentence because depend on the topic". For example: with these simple words, launched America's improbable experiment in democracy. Students' translation "dengan kata-kata sederhana meluncurkan eksperimen mustahil Amerika dalam demokrasi". the word underlined not appropriate, it could be changed another meaning 
Globish (An English-Indonesian journal for English, Education and Culture)

Vol. 9 No.2 July 2020

P-ISSN: 2301-9913, E-ISSN: 2597-9132

DOI: http://dx.doi.org/10.31000/globish.v7i2

such as "mengutarakan" because the context is an opinion. Thus "mengutarakan" is prefer than "meluncurkan".

The researchers have completed and got the data from all technique included Interview, Observation, and Documentation. The researcher has given the test to the sixth semester of Muhammadiyah University of Tangerang about translating Obama's speech text, from 14 students. To gain the objective of research, researcher has analyzed the data systematically and accurately. In reporting findings of the research, the researcher reported the result based on the topic in research problem. To find out delivering message and equivalent words based on characteristics some expert :

a. Characterics of delivering message from some expert:

1. The originator of the message in the communication process is the sender, the sender conveys the message to a receiver (Nordquist, 2018).

2. Students are trained to transfer meaning or message from the source text (ST), English, and to restructure it into the target text (TT), Indonesian. The materials used to train them are humor-of-situation texts of which language is not too difficult so that students can focus their attention in transfering the meaning or message or content of ST into TT (Rini, 2007).

3. The media, the experts, will be transferring words whether the translators like it or not. Perhaps when the translator's professional status is raised, they will not be transferring so many (Newmark, 1988).

b. Characteristics of equivalency from some expert:

1. This common procedure, applied to cultural words, requires the use of a culture-free word, sometimes with a new specific term; it therefore neutralises or generalises the SL word; and sometimes adds a particular thus: baccalauriat - Trench secondary school leaving exam'; Sejm - 'Polish parliament1; 'Roget' - dictionnaire ideologique anglais. (Newmark, 1988).

2. In the stage of restructuring, translators write the TT, maintaining the equivalent content, meaning and message of the ST (Rini, 2007).

3. Equivalence as the translation of idioms when two languages refer to the same situation in totally different ways. It is actually different with calque which uses same meaning and form of thing in the SL and TL (Nur'azizah, 2015). 


\section{CONCLUSION}

The researchers would like to draw some conclusion to answer the statement of the problem of this research as stated in the previous chapter. The first is difficulties in delivering message from source language into target language on sixth semester B.1 at Muhammadiyah University of Tangerang, and the second one is difficulties in using equivalent words on sixth semester B.1 at Muhammadiyah University of Tangerang. For the first problem is delivering message. Based on the student's result in delivering message, some students feel difficulties and confuse when transferring the message from SL into TL, there are sentences that is not delivered well and make confused to the readers. It shows that the students still need practice in translation.

The second problem is how the students use equivalent words. Based on the student's result in equivalency, most of the students still lack in vocabulary, it shows from student's result that translated from SL into TL. There are from students feel confuse to change the meaning into another meaning but not change the message. Thus, students should practice to translate SL into TL in order to could make the result from translation good and easy to be understood by the readers. The source language is done translated into target language by the students, and the result based on the research question, most of the student should practice to translate source language into target language in order to understand how to be a good translator, and they need guidance's from their teacher, lecturer, or expert.

\section{REFERENCES}

Ardeshiri, M., \& Zarafshan, M. (2014). “Students' Causes of Errors in Translating Pragmatic Senses." International Journal of English and Education. ISSN: 2278-4012, Volume:3, Issue:4.

http://www.ijee.org/yahoo site admin/assets/docs/pdf

(Accessed on December 25, 2018 19:00)

Dalton, W. (2009, February Friday). Pengertian Tes, Pengukuran, Evaluasi dan assesment. http://wiliandalton.blogspot.com/2009/03/pengertian-tespengukuran-evaluasi-dan.html?m=1.

'(Accessed on February 26, 2019 20:35) 
Hamid, R. and Pujiantri, R. (2013). "Improving The Students' Ability In Translating English Into Indonesian Based On Duff's Principles." Vol. 2 No. 2.

http://322067956 Improving the students' ability in translating English in to Indonesian based on Duff's principles.pdf. (Accessed on January 20, 2019 19:36)

Newmark, P. (1987). A Text Book of Translation (E-book). First published 1988 by Prentice Hall International. Shanghai foreign language education press.

Nordquist, R. (2018, june 04). ThoughtCo. Humanities > Languages. The definition of message in communicattion.

http://www.thought.com/message-communication-term

(Accessed on may 07, 2019 20:48)

Nur'azizah, W. (2015). "An Analysis Of Students' Translation Works Of A Barack Obama's Political Speech." Journal of English and Education. 3(1), 134-144. http://ejournal.upi.edu/index.php/L-E/article/view/4616

(Accessed on January 25, 2019 20:12)

Obama, B. (2008). Race Speech at the Constitution Center Transcript. National Constitution Center.

http://constitutioncenter.org/amoreperfectunion/docs/Race Speech Transc ript.pdf

(Accessed on October 20, 2018 20:50)

Rayendar. (2015, June Friday). Metode Penelitian menurut Sugiyono 2013.

http://rayendar.blogspot.com/2015/06/metode-penelitian-menurutsugiyono-2013.html? $\mathrm{m}=1$

(Accessed from blog on march 5, 2019 20:35)

Regmi, K. (2010). "Understanding the Processes of Translation and Transliteration in Qualitative Research." International Journal of Qualitative Methods 9(1) http://journals.sagepub.com/doi/licenses/10. (Accessed on December 25, 2018 18:15)

Rini, J.E (2007). "Difficulties in Translating Text for Beginner Translator Students" volume 9 (2) December 2007 169-178.

http://kata.petra.ac.id/index.php/ing/article/view/16690 (Accessed on april 24, 2019 21:15)

Silviana, E. (2012). "an analysis of students' difficulties in translating narrative text ( a case study at eleventh grade of SMK Hass Ashabulyamin Cianjur)." Reg.No. 08220072/PBS. http://publikasi.stkipsiliwangi.ac.id/files/2012/12/08220072-erry-s.pdf. (Accessed on October 20, 2018 14:49)

Sugiyono. (2015). Metode Penelitian Pendidikan. Cetakan ke-21. Bandung: Alfabeta.

Tarigan, K. E. (2018) “An analysis of students' difficulties in translating descriptive text". SEJ (School Education Journal) vol. 8.2. http://jurnal.unimed.ac.id/2012/index.php/school/article/pdf. (Accessed on November 27, 2018 22:10) 
P-ISSN: 2301-9913, E-ISSN: 2597-9132

DOI: http://dx.doi.org/10.31000/globish.v7i2

Yasin, B., Fata, I. A. \& Husyitiara. (2018). "Analyzing the English Translation of the Novel 'Laskar Pelangi (The Rainbow Troops).” 5(1), 54-68, 2018.

https://doi.org/10.24815/siele.v5i1.9864

(Accessed on December 25, 2018 18:58)

Zoraya, R., \& Sutopo. D., \& Yuliati. (2017). “Analysis Of Unit-Shifts In A Subtitle Of The Hobbit Third Sequel." Journal of English Language Teaching 6 (2).

http://Journal.unnes.ac.id/sju/index.php/elt.pdf.

(Accessed on January 20, 2019 19:36) 